УДК 622.822

\title{
ТИПЫ ГРУНТОВ ЗЕМЛЯНОГО ПОЛОТНА ЖЕЛЕЗНЫХ ДОРОГ КАЗАХСТАНА
}

\author{
Канд. техн. наук К.Т. Омарова
}

ТИПИ ГРУНТІВ ЗЕМЛЯНОГО ПОЛОТНА ЗАЛІЗНИЦЬ КАЗАХСТАНУ

\author{
Канд. техн. наук К.Т. Омарова \\ TYPES SUBGRADE SOIL RAILWAY OF KAZAKHSTAN
}

Cand. of techn. sciences K.T. Omarova

Автор в своей статье рассматривает типь грунтов земляного полотна железных дорог Казахстана. Влияние некоторых факторов на накопление остаточных деформаций изучено больше (например, роль загрязнения балласта), а роль некоторых конструктивных и технологических факторов изучена недостаточно, хотя их учет может существенно повысить эффективность бесстыкового пути. Статья выполнена на актуальную для магистральных железных дорог Казахстана тему.

Автором установлен грунтовый фон по уровням залегания толщиной 1 м до глубинь 5 м, который позволяет правильно проектировать железнодорожные сооружения, прогнозировать условия строительства и эксплуатаџии железных дорог.

Ключевые слова: железная дорога, земляное полотно, тип грунта, бесстыковый путь, деформачия.

Автор у своїй статті розглядає типи трунтів земляного полотна залізниць Казахстану. Вплив деяких факторів на накопичення остаточность деформацій вивчено більше (наприклад, роль забруднення баласта), а роль деяких конструктивних $i$ технологічних факторів вивчена недостатньо, хоча їх облік може істотно підвищити ефективність безстикової колії. Стаття виконана на актуальну для магістральних залізниць Казахстану тему.

Автором встановлено трунтовий фон за рівнями залягання товщиною $1 м$ до глибини 5 м, який дозволяє правильно проектувати залізничні в -ні споруди, прогнозувати умови будівництва та експлуатації же залізних доріг.

Ключові слова: залізниця, земляне полотно, тип грунту, безстиковий шлях, деформачія.

The author in his article examines types of subgrade soil of Kazakhstan railways. The influence of some factors on the accumulation of residual strains studied more (for example, the role of contamination of ballast), and the role of some structural and technological factors is not well understood, although their inclusion can significantly improve the efficiency of continuously welded rail. Article is made to the current for main railways of Kazakhstan topic.

The author determines the compactor on the background levels of occurrence of thickness $1 \mathrm{~m}$ to a depth of 5 meters, which allows you to properly design the railroad facilities, to predict conditions for the construction and operation of railways.

Keywords: railway, subgrade, soil type, continuously welded rail, deformation.

Изучение и оценка физико- пород необходимы для проектирования, механических свойств грунтов и горных строительства и эксплуатации пути и 
являются одной из наиболее сложных и наименее изученных проблем в области физических процессов, происходящих в горном массиве и основании железнодорожного пути. На практике изучение свойств грунтов и горных пород ограничивается лабораторными исследованиями, без учета динамических воздействий подвижного состава на путь и длительности эксплуатации железных дорог. Такой подход не удовлетворяет запросы проектировщиков, строителей и тех, кто эксплуатируют железные дороги, поэтому необходимо изучить и оценить грунтовое основание магистральных и карьерных железных дорог, что позволит определить вероятность появления грунтов различного типа, лежащих в основании железных дорог, а также пределы изменения физико-механических свойств наиболее распространенных грунтов.

На основании этих данных составлена карта районирования территории республики с выделением зон, а также разработаны рекомендации и основные инженерные решения по проектированию, строительству и эксплуатации железных дорог.

Первая карта-схема климатического районирования в бывшем СССР была разработана А.В. Гербурт-Гейбовичем, в которой по условиям осеннего увлажнения грунтов, длительности зимнего периода эта территория была разделена на 6 зон и 16 подзон. В последующие годы карта-схема районирования неоднократно пересматривалась, в начале 1970-х годов появляется значительное количество работ, освещающих различные аспекты районирования [1, 2].

В 1974 году А.А. Малышев и другие
[1] публикуют $\quad$ новую схему районирования. Относительная однородность выделенных районов установлена по четырем факторам: вид грунта сезоннооттаивающего слоя; его влажность; характер распределения вечномерзлых грунтов и их температур; мощность деятельного слоя.
Занимаясь вопросами районирования, B.М. Сиденко предложил перейти от дорожно-климатического к дорожному районированию, представляя его как метод объединения однородных территорий по каким-либо признакам, которые оказывают существенное влияние на проектирование, строительство и эксплуатацию дорог [2]. Он ставит вопрос о необходимости разработки зональных технических условий, которые должны отражать особенности природных условий и специфику проектирования, строительства и эксплуатации дорог в каждой зоне, дополнив Строительные нормы СН 449-72.

Основными признаками подзон является высокая температура в летние месяцы и недостаток влаги, вызываемые значительным преобладанием испаряемости атмосферных осадков. Вся территория подзон характеризуется разнообразием природных условий, климата, грунтов, рельефа местности и гидрогеологии.

Из зарубежных работ, посвященных данной теме, можно выделить работу «Зависимость проектирования дорог от местных физико-географических условий», где обобщены сведения о местных дорожно-строительных материалах, несущей способности грунтов и их изменениях под влиянием увлажнения [3]. По комплексу этих условий территория США разделена на 97 физикогеографических районов.

По данным В.М. Сиденко [4-6], в рассматриваемых подзонах распространены сероземы, пески и почвы горных районов. Сероземы макропористые, отличаются высоким содержанием в грунтах пылеватых частиц, преобладанием легких пылеватых суглинков и тяжелых пылеватых супесей. Они относятся к пучинистым и сильнопучинистым грунтам, легко размокают при увлажнении, в сухом состоянии плохо сопротивляются внешним воздействиям и на грунтовых поверхностях под действием автомобилей быстро 
истираются и превращаются в несвязную мaccy [4-7].

Поэтому возможность использования сероземов для возведения полотна и ПДПД укрепления откосов и основной площадки сезоннопромерзаемого полотна должна подтверждаться лабораторными данными.

Песчаные почвы пустынь слабо дифференцированы по физическим свойствам и имеют низкую максимальную гигроскопичность (1,6 + 3) \%, влагоемкость $(10+12) \%$, высокую водопроницаемость (1300 мм за 10 час) и капиллярное поднятие не более $(0,80+1,00)$ м.

Максимум водорастворимых солей редко превышает 1 \% и расположены они на глубине около 1 M. Среди солей преобладают сульфаты. Территории с песчаными почвами являются наиболее трудными для строительства и эксплуатации железных дорог.

Для исследования распространенности грунтов в земляном полотне и его основании железные дороги Республики Казахстан были разделены на шесть условных зон (рисунок).

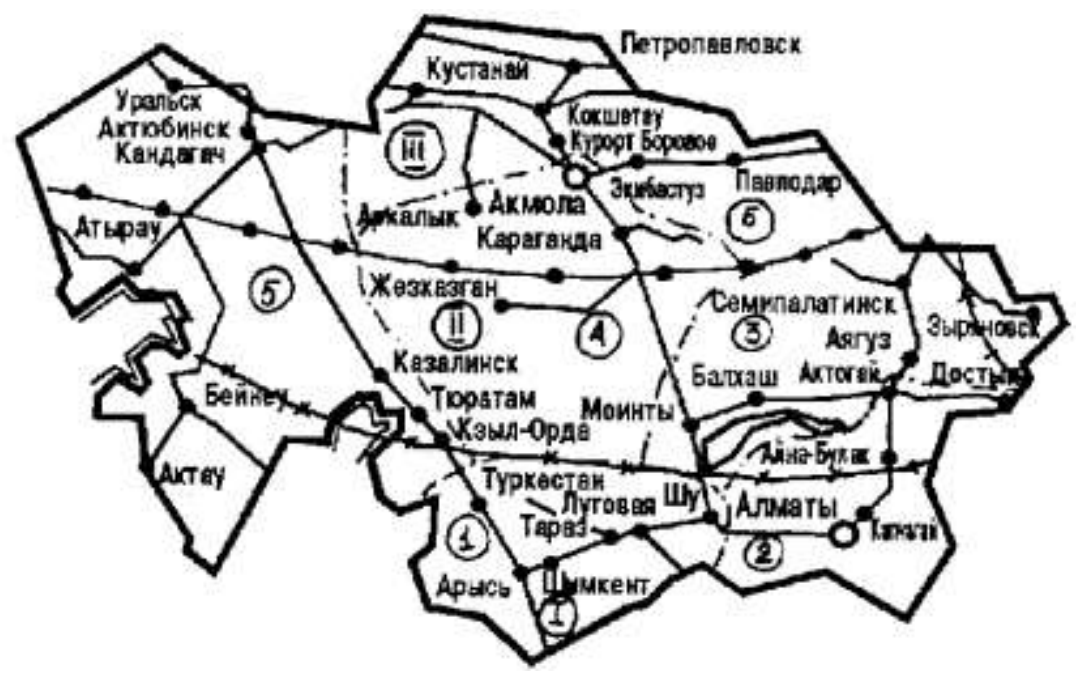

Рис. Условные зоны железных дорог Казахстана:

I - территория по глубине промерзания грунта до 1 м; II - территория по глубине промерзания грунта от 1 до 2 м; III - территория по глубине промерзания грунта свыше 2 м; 1,2,3,4,5 - зоны территории железных дорог Казахстана

- Южная, № 1 (участки железных дорог: Сатимсак - Ченгельды, Шу Тюлькубас, Тюлькубас-Ченгельды);

- Юго-Восточная, № 2 (участки железных дорог: Моинты - Сары-Шаган, Сары-Шаган - Шу, Шу - Отар - Алматы, Алматы -Сары-Озек, Сары-Озек - Актогай, Актогай - Дружба);

- Восточная, № 3 (участки железных дорог: Актогай - Семипалатинск, Семипалатинск - Бельагаш, Шемонаиха Зыряновск);
- Центральная, № 4 (участки железных дорог: Астана - Осакаровка, Осакаровка - Южный, Южный - Мойнты, Жарык - Жезказган, Мойнты- Саяк, Саяк Актогай);

- Западная, № 5 (участки железных дорог: Кандагач - Саксаульская, Саксаульская - Сатимсак, Уральск Чингирлау, Яйсан - Кандагач, Кандагач Аты- рау, Кандагач - Сагиз, Сагиз Атырау, Макат - Опорный, Опорный Узень); 
- Северная, № 6 (участки железных дорог: Железорудная - Койбагар, Койбагар - Сергеевка, Сергеевка - Астана, Астана Макинск, Макинск - Новоишимская, Новоишимская - Кустанай, Астана Ерментау, Ерментау - Павлодар, Есиль Аркалык).

Статистические данные о грунтовых условиях земляного полотна и оснований железных дорог Казахстана были систематизированы по данным институтов Казгипрожелдорпроекта,

ГПИ Каздорпроекта, Гидроводхоза, КазГИИЗа и их областных филиалов. Для определения физико-механических свойств грунтов и пород оснований железных дорог было собрано 16000 паспортов грунта, в том числе по зонам: Южная и Юго-Восточная 4100; Восточная - 2500; Центральная 4200; Западная - 2700; Северная - 3400 [8].

В связи с тем, что глубина выемок на железных дорогах страны не превышает 5,0 $\mathcal{M}$, для получения качественной характеристики различных типов грунтов были использованы паспорта грунтов, равномерно распределенных на этой глубине. Обработка материалов по грунтовому фону производилась с использованием ЭВМ. Распределения грунтов по типам производились также по глубине: от 0 до $1,0 \mathrm{M}$, от 1,0 до 2,0 $\mathrm{M}$, от 2,0 до 3,0 $\mathrm{M}$, от 3, до 4,0 $\mathrm{M}$, от 4,0 до 5,0 $\mathrm{M}$, от 0 до 5,0 $м$ для каждого направления дороги.

При исследовании грунтов по типам рассматривались: скальные и полускальные; крупнообломочные, которые были разделены на валунные, галечниковые, гравийные; песчаные - на песок гравелистый, песок крупный и средней крупности и песок мелкий и пылеватый; глинистые - на супесь, суглинки и глины. При рассмотрении глинистых грунтов отдельно выделялись песчаные и глинистые с каменистыми включениями до $25 \%$.

Пользуясь данными паспортов, можно определить вероятность появления различных типов грунтов в основании земляного полотна, а также установить наиболее распространенные типы грунтов на различных глубинах. В Юго-Восточной зоне на поверхности основания земляного полотна самыми распространенными являются глинистые грунты $(P=0,631)$, песчаные грунты имеют вероятность появления $P=0,226$, крупнообломочные $P=0,134$, а остальные составляют скальные и полускальные грунты.

Действительно, в этой зоне железная дорога пересекает несколько горных перевалов (Архарлинский, Чокпарский, Машатский). На этой территории расположены песчаные пустыни Кызылкум, Мойынкум и глинистая пустыня Бетбак-Дала.

В Южной зоне на поверхности основания земляного полотна самыми распространенными грунтами являются глинистые и песчаные грунты $(P=0,571 u$ $P=0,382)$, крупнообломочные с вероятностью $P=0,034$, а остальные составляют скальные и полускальные грунты. С возрастанием глубины распространенность песчаных грунтов возрастает.

В Западной зоне на поверхности основания земляного полотна самыми распространенными являются глинистые грунты $(P=0,788)$, песчаные грунты имеют вероятность появление $P=0,202$, крупнообломочные, скальные и полускальные грунты в этой зоне имеют незначительное распространение. С возрастанием глубины распространенность выше указанных грунтов не меняется. В этой зоне железная дорога пересекает пески Большие и Малые Барсуки в районе станции Шалкар, а также проходит через горы Мугаджар. В Мангышлакской области железная дорога проходит по западной части Устюрта. К западу от реки Урал более распространены песчаные пустыни, а к востоку и югу - глинистые.

На севере Казахстана на поверхности основания земляного полотна самым распространенным грунтом являются глинистые грунты $(P=0,788)$, песчаные 
грунты имеют вероятность распространения $P=0,202$. Крупнообломочные, скальные и полускальные грунты в этой зоне имеют незначительное распространение. Однако на глубине 2-3 м возрастает распространенность скальных и полускальных грунтов. Действительно, значительную часть этой территории занимает Казахский мелкосопочник. Из глинистых грунтов самым распространенным является суглинок с вероятностью появления $P=0,484$. Вероятность появление супеси $P=0,243$, а глины - $P=0,204$.

В Центральном Казахстане на поверхности основания земляного полотна самым распространенным грунтом являются глинистые грунты $P=0,578$ и крупнообломочные грунты $P=0,274$. В этой зоне песчаные грунты имеют вероятность $P=0,102$, возросла распространенность скальных и полускальных грунтов, так как значительную часть этой территории занимает Казахский мелкосопочник.

Рельеф Восточного Казахстана, в отличие от Центрального, весьма разнообразен. Здесь четко выделяются слабохолмистые равнины и среднегорья, обширные котловины и высокие горы. В Восточном Казахстане на поверхности основания земляного полотна самым распространенным грунтом являются глинистые грунты $(P=0,638)$ и крупнообломочные грунты $(P=0,214)$. В этой зоне песчаные грунты имеют самое малое распространения $(P=0,082)$, возросла распространенность скальных и полускальных грунтов по сравнению с юговостоком Казахстана. Действительно, значительную часть этой территории занимают заснеженные хребты Саура и Тарбагатая, между ними и Южным Алтаем расположена обширная Зайсанская котловина. Из глинистых грунтов самым распространенным является суглинок, вероятность появления которого достигает $P=0,492$, супеси - $P=0,123$, а самой глины $P=0,024$.

Анализ вероятности появления грунтов различного типа оснований железных дорог по территории Казахстана показал, что в основаниях железных дорог Центральной, Восточной и Юго-Восточной зон имеется появление крупнообломочных грунтов (соответственно $P=0,274, P=0,214$, $P=0,134)$, а по данным работы [9], для Азиатской части бывшего СССР вероятность их появления не превышает $P=0,097$.

Земляное полотно железных дорог Казахстана в основном лежит на глинистом грунте - 79\%, на песчаных грунтах находятся $17,4 \%$, а на крупнообломочных $11,4 \%$. На скальных и полускальных грунтах расположены 2,2 \% железных дорог.

Статистические характеристики (математические ожидание, дисперсия, коэффициент вариации) распределения грунтов, определенные с помощью ЭВМ с надежностью 0,9 + 0,95, представлены в таблице.

Таблица

Статистические характеристики грунтов

\begin{tabular}{|l|c|c|c|c|c|c|c|}
\hline \multirow{2}{*}{$\begin{array}{c}\text { Статистиче- } \\
\text { ские характе- } \\
\text { ристики, } x_{c p}\end{array}$} & $\begin{array}{c}\text { Песча- } \\
\text { ный }\end{array}$ & Супесь & $\begin{array}{c}\text { Суглинки } \\
\text { Средний }\end{array}$ & $\begin{array}{c}\text { глины } \\
\text { тяжелые }\end{array}$ & $\begin{array}{c}\text { глины с } \\
\text { включе- } \\
\text { нием }\end{array}$ & $\begin{array}{c}\text { Крупно- } \\
\text { обломоч- } \\
\text { ный }\end{array}$ & $\begin{array}{c}\text { Гравий- } \\
\text { но- } \\
\text { галечный }\end{array}$ \\
\hline $\begin{array}{l}\text { Математи- } \\
\text { ческое ожи- } \\
\text { дание, } \sigma\end{array}$ & 1,24 & 1,61 & 1,54 & 3,06 & 2,90 & 3,66 & 3,55 \\
\hline Дисперсия & 1,08 & 1,30 & 1,32 & 0,79 & 1,17 & 1,32 & 1,40 \\
\hline $\begin{array}{l}\text { Коэффициент } \\
\text { вариации, } v\end{array}$ & 0,84 & 0,70 & 0,74 & 0,29 & 0,37 & 0,31 & 0,33 \\
\hline
\end{tabular}


Выводы. Установлен грунтовый фон по уровням залегания толщиной 1 м до глубины 5 м, который позволяет правильно проектировать железнодорожные сооружения, прогнозировать условия строительства и эксплуатации железных дорог.

Исследованием установлено, что наиболее распространенными типами грунтов в 5 м поверхностной толщи грунтов оснований земляного полотна железных дорог Казахстана являются глинистые грунты (с вероятностью появления $P=0,595)$, песчаные $(P=0,259)$, крупнообломочные и скальные $(P=0,125 u$ $P=0,021)$. Теоретические законы распределения различных типов грунтов подчиняются, с надежностью $0,90+0,95$, по уровням залегания от 0 до 1 м закону Вейбула, от 7 до 3 м - нормальному закону, от 3 до 5 м - логнормальному закону.

\section{Список использованных источников}

1. Малышев, А.А. Земляное полотно автомобильных дорог в северных условиях [Текст] / А.А. Малышев [и др.]. - М.: Транспорт, 1974. - 279 с.

2. Сиденко, В.М. Автомобильные дороги (Совершенствование методов проектирования и строительства) [Текст] / В.М. Сиденко [и др.]. - К.: Будівильник, 1973. - 76 с.

3. Filing system of physiographic units helps to resolve local design criteria [Text]. Highway Res. News. - 1973. - № 51. - P. 42-43.

4. Сиденко, В.М. Проектирование, строительство и организация возведения земляного полотна в засушливых районах [Текст]: учеб. пособие для студентов автодорожных спец. вузов / В.М. Сиденко, Н. Ильясов. - Т.: Укитувчи, 1983. - 288 с.

5. Сиденко, В.М. Расчет и регулирование водно-теплового режима дорожных одежд и земляного полотна [Текст] / В.М. Сиденко. - М.: Автотрансиздат, 1962. - 156 с.

6. Водно-тепловой режим земляного полотна и дорожных одежд [Текст] / Н.А. Пузаков, В.М. Сиденко [и др.]; под ред. проф. И.А. Золотаря. - М.: Транспорт, 1971. - 416 с.

7. Безрук, В.М. Укрепление грунтов в дорожном и аэродромном строительстве [Текст]. - М.: Транспорт, 1971. - 247 с.

8. Омаров, А.Д. Грунтовый фон оснований железных дорог Казахстана [Текст] / А.Д. Омаров; под ред. д.т.н., проф. Р.А. Кабашева. - Алматы: «Ғылым», 1998. - 110 с.

9. Баловнев, В.И. Моделирование процессов взаимодействия со средой дорожных органов дорожно-строительных машин [Текст]. - М.: Высш. шк., 1981. - 335 с.

Рецензент д-р техн. наук, профессор Т.С. Саржанов

Омарова Кумыс Толеубековна, кандидат технических наук, доцент, доктор PhD по специальности «Строительство» 6 D072900 ГУТиП им. Д. Кунаева.

Omarova Kumiss Toleubekovna, cand. of techn. sciences, dr. PhD in "Construction of the" 6 D072900, associate professor. 